\title{
Expanding supported employment opportunities
}

Within less than a decade, the national number of people participating in supported employment in the U.S. has increased from 9800 to over 110000. Many thousands more are working for the first time in countries all over the world. These are individuals who historically were confined to adult activity centers, sheltered workshops, nursing homes, and institutions with unlikely competitive employment futures. However, the use of trained employment specialists, informed co-workers and mentors, and other technological supports have elevated the work possibilities for people with significant disabilities.

Unfortunately, hundreds of thousands of people with disabilities still remain behind in segregated centers. Many more are on waiting lists for employment despite the fact that people with significant cognitive, physical, and behavioral challenges have shown their competence in the workplace.

These employment successes are not episodic or isolated, nor are they confined to any one region of the country or the world. Now, there is an Association for Persons in Supported Employment (APSE), a European Union of Supported Employment, and an emerging World Association on Supported Employment. Many states in the U.S. and countries throughout the world have supported employment chapters of people with disabilities, advocates, and professionals working together to make real work a viable option. The growth of supported employment as a real work option has emerged over the less attractive alternatives of segregation as the timeline of events in the accompanying figure shows.
However, much more needs to be done. Even though many people with disabilities and their families want real employment opportunities, the vast majority have been unable to sufficiently mobilize their communities to make this happen. There are many reports which indicate that people with disabilities want to work, ranging from anecdotal case studies to more scientific analyses such as the Louis Harris Poll conducted in the U.S. in 1994.

Real work as an option should be an issue upon which all can agree. All players involved benefit from supported employment. The individual with a disability, often for the first time, has a real job, benefits, and dignity. The employer gets a good worker and receives specialized support to train and maintain the individual. The family will be able to see their family member in a fully competent role in the workplace. Finally, taxpayers will spend less money than they would to support the individual in a segregated day program year in and year out. The question remains: Why are the vast majority of individuals with mental and physical disabilities remaining in segregated day programs?

The answer lies in the inability of advocates and people with disabilities to sufficiently marshal their collective efforts to increase work opportunities. The adult service systems in the world are deeply entrenched and have been for several decades. To change this way of providing services, particularly in times of reduced funding and a serious fiscal crunch, is extremely difficult. Hence, there is an overwhelming necessity to market the positive attributes of supported em- 


\begin{tabular}{|c|c|c|c|}
\hline 1950-1978 & 1978-1985 & 1985-1992 & 1992-1995 \\
\hline $\begin{array}{l}\text { Major domination of } \\
\text { sheltered workshops/adult } \\
\text { activity centers/state } \\
\text { institutions for mildly and } \\
\text { severely disabled. } \\
\text { Well over } 1,000,000 \\
\text { persons in } 5,000 \\
\text { segregated day programs } \\
\text { in U.S. alone. }\end{array}$ & $\begin{array}{l}\text { - } \begin{array}{l}\text { Placement into real } \\
\text { work/competitive } \\
\text { employment occurs at } \\
\text { selected university } \\
\text { centers on a } \\
\text { research/demonstration } \\
\text { basis. }\end{array} \\
\text { Focus on those with } \\
\text { mental retardation only. } \\
\text { Emergence of the term } \\
\text { "job coach." }\end{array}$ & $\begin{array}{l}\text { - } \begin{array}{l}\text { National acceptance and } \\
\text { growth of supported } \\
\text { employment via several } \\
\text { federal laws with } \\
\text { funding in U.S. }\end{array} \\
\text { Expansion into all } \\
\text { severe disabilities. } \\
\text { - } \quad \text { All } 50 \text { states in U.S. } \\
\text { offer programs/with } \\
3,000 \text { programs offering } \\
\text { SEP option. } \\
\text { Growth is } 10,000 \text { to } \\
105,000 \text { persons (still } \\
\text { leaves close to one } \\
\text { million in day programs } \\
\text { in U.S.) }\end{array}$ & $\begin{array}{l}\text { Supported employment } \\
\text { growth continues } \\
\text { internationally. European } \\
\text { Union of Supported } \\
\text { Employment/World } \\
\text { Association of SEP } \\
\text { emerges as major force. } \\
\text { Efficacy of SEP challenged } \\
\text { by well entrenched adult } \\
\text { day centers. } \\
\text { Natural supports given } \\
\text { greater emphasis. }\end{array}$ \\
\hline
\end{tabular}

Fig. 1. Timeline of supported employment growth and emergence.

ployment for people with significant disabilities on a community level.

Unfortunately, we in the supported employment community, and even more broadly within the greater disability community, have not told our story well. We have not communicated the successes of this approach nor the positive impact that work has on the lives of people who historically have been disenfranchised and written off as incompetent.

As an interested society, we must get past the notion that people with severe disabilities are unable to work and do not want to work. There are ways to do this. Here are eight recommendations for 1996:

1. Encourage or require local communities to develop plans which specify the steps participating agencies will take to expand the development of integrated employment alternatives in their communities.

2. Provide financial incentives to local provider agencies for placement of individuals with disabilities into competitive employment.

3. Funding agencies must attempt to reimburse supported employment providers for the actual costs of providing services, or at a minimum, refrain from artificially deflating reimbursement rates for supported employment in relation to other employment alternatives.
4. Individuals with disabilities and advocacy organizations should press for the aggressive implementation of the consumer empowerment.

5. Voucher systems, or other approaches that enable consumers to directly control the resources allocated to support their needs and desires, should be developed, validated and refined for widespread implementation.

6. The focus of supported employment efforts should be on careers, not jobs.

7. The emphasis on career development, preparing an individual for a series of jobs leading toward an overall career goal, as opposed to isolated training geared toward a specific job, should be the focus of secondary and postsecondary educational experiences for individuals with disabilities.

8. Develop strategies designed to directly address negative attitudes often held by employers and coworkers.

We have the ability and capacity to help hundreds of thousands of persons with severe disability work. But we must change our government policies, especially to those provider programs that control the human service funds. Do we have the collective will to do so?

Paul Wehman Editor 